\title{
Social Media and Students' Academic Performance in Nigeria
}

\author{
Suleiman A. Ahmad \\ Department of Educational Foundations, Federal University Dutsinma \\ Katsina State, Nigeria \\ Email: saahmad [AT] fudutsinma.edu.ng
}

\begin{abstract}
The focus of this study is to find out effect of social media on students' academic performance of students at the Federal College of Education, Kontagora in Niger State of Nigeria. By use of random sampling, a total sample of 100 students was selected. Questionnaire was used as an instrument for data collection. Result of the study indicates that effect of social media can be both positive and negative. The social media sites such as Twitter, WhatsApp, Facebook, Instagram were the most used that capture the attention of many students away from their study and thus have negative and positive effects on their academic grade points aggregate.
\end{abstract}

Keywords - Social Media, Students, Nigeria, Academic, Performance

\section{INTRODUCTION}

Social media emanates since the time when people started to communicate. Social refers to human society, as interference of people. The word media is use of other medium to make expressions. Most of the forms of social media are not digital. It generates a large number of innovations therefore, social media is one of the biggest inventions of technology, which is now most popular and widely used. Social media is defined by Boyd (2007) as "technologies that made social communication easy and enable discussion among its participants". Pp 20. The social media can equally means a webbased mobile application that allows people or companies to make, interact with, and share new user-generated or current material, in digital environment. Students form large part of users thus becoming both consumers and producers of information on the media. The use of social media has now become comprehensive and much widely among students. (Zahid., Ahmad, Syed. \& Faisal, 2016). they further stated that the most popularly used are Facebook, Twitter, MySpace, LinkedIn, Google+, Skype, Facebook. On all of these social media platforms, users profile allow the users to communicate information with each other and allow users to build on their own and maintain relationships and become popular as well. It is also used to connect with other students and members of faculty within and outside the classrooms.

There are advantages for universities and colleges that can be gained by connecting with students through the use of social media. Firstly, it increases the level of thinking and it builds chains of communication; secondly, it helps can be used to discuss study materials, connect with classmates, and organize study groups. The use of smart phone has increased the usage of social media. It thereby enables users to access multiple social networking sites through just a few clicks. Some studies prove that social media negatively affect performance of students while to some, it improves learning and communications skills. (Lenhart, Purcell, Smith, \& Zickuhr, 2010).

The world, in recent years, experiences changes and is celebrating modern technology in communication. This turns the entire world into what is referred to as a 'global village'. Nonetheless, technology is just like two sides of a coin. It brings with it both negative and positive effects. Technology helps people to be well informed, set enlightened and thus keeping people abreast of it as well with all developments across the world. The issue of social media technology exposes a lot of people to a far more better ways of doing a lot of things. The world is rapidly changing day by day through the evolution of such technology; this has resulted into the use of technologies as the most important medium to explore a wide area of knowledge. (Sharive, 2018).

He further states that academic performance is the outcome or result of education. It is the extent to which a student learner, teacher or institution has achieved their educational goals. Academic performance is commonly measured by continuous assessment, in form of test or assignment and finally an examination. But there is no general agreement on how it is best tested or which aspects are most important.

Sharive, (2018) opined that there has been a direct relationship that exists between social media usage and the academic performance of students. However, the negative side within technological evolution has resulted in a kind of dilemmas and setbacks of real values of life. Many students are now addicted to the online activities of social media like Facebook, 
Twitter and so forth as well as games. As such, student's academic performance is effected by a large number of factors but the impact of social media on the performance of student is most important than any other factor. Das and Sahoo (2010) stated that people consume additional time in interacting with their friends to access and or share information on social media platforms. So, they become addicted to always look over and verify their status after every few minutes in a day.

The educational system in Nigeria is faced with so many challenges which have certainly brought the quality of education to a decline. There is a kind of deviation, distraction and divided attention between social networking activities and academic work common among the students and even teachers. It is observed that students spent more attention to social media than they do on their studies. It is quite clear that students' addictiveness to social media, their frequency of exposure to social network sites have exposed and influence their interaction and academic pursuit as well as impacted hard on their academic performance. it is observed that instead of students reading their books, they spend much of their time chatting and making friends on the social media and this might have definitely influence their performance academically. This phenomenon has become a source of worry to many who believe in knowledge and skill acquisition. (Sharive, 2018)

Social media have become a major stay in the minds of students and the world at large thereby causing a lot of drastic measure on students, teacher and even educational administrators at large. It is therefore of great importance to explore some of such trending issues facing students' academic performance vis a vis social media.

\section{OBJECTIVES}

The broader aim of this study is to examine the effects of social media on the students' academic performance. The other specific objectives of the study are as follow;

1. To ascertain how the use of social media do influence the academic performance of the students.

2. To find out whether the use of social media has any positive or negative influence on their academic performance

\section{RESEARCH QUESTIONS}

The following are the research questions raised for the study;

1. How does the use of social media influence the academic performance of the students?

2. Do the use of social media has any positive or negative influence on students' academic performance?

\section{LITERATURE REVIEW}

Social networking sites, or social media as they are popularly called are much admired by not only youth but all categories of people globally. It is a new paradigm that attracts the interest of all and sundry involving both the academics and non-academics all together. Social media cut across all endeavour and aspects of life education inclusive. Such online environments like Facebook, Twitter, and YouTube to mention a few are seen as hubs and platforms that many people rely on for their day to day interactions in terms of business, education, politics, sociology, religion and host of other affairs (Suleiman, 2014).

Social networking sites (social media) are becoming popular online terminus in recent years. Students are found to be highly engaged in using social media. The user attraction level has been accompanied by wide coverage in popularity of press, including speculations about the potential advantages gained as well as harms stemming from the use of such social media services (Suleiman, 2014; Shambare, Rugimbana, \& Sithole, 2012). Academic researchers have started studying these social media, with questions ranging from type, mode and time of usage; roles, identity construction; expression of views, building and maintenance of socialization and relations as well as social capital which all round concerns about morality alongside privacy. One major point of concern is that, it is not yet quite clear whether using social media enhance academic adjustment bearing in minds that student are heavy users of the social media. He further hold the view that academic adjustment can therefore refers to as students' adoption and adaption to changes in their attitudes, behaviors, values, rules, regulations and academic achievement and performance of the school environment. (Suleiman, 2014; Zahid et al, 2016)

Social media is argued to have negative results on students and younger generation whereas there were arguments that it has positive effect on students which cause them have their high results grade. Some studies also argued that students spent most of their time on such activities and easily completed their home assignments and projects. (Lenhart, et al 2010; Sharive, 2018)

Shambare, et al. (2012) reported that such media most commonly used by young students have multiple effects on their life. Ahmad (2011) showed that social networking sites have number of advantages for their users, it enable the community to keep in touch with their peers and re link with old ones as well as finding new friends of interest from all around which resulted to a large number of persons linking with each other forming a large networks. 


\section{SOCIAL NETWORKING SITES}

The early beginning of online social media can be traced to 2001 when it openly started (Boyd \& Ellison, 2007). A number of online community tools sprang and began supporting various combinations of profiles and publicly articulated friends. Social network sites became are becoming popular online terminus since last decade. Boyd and Ellison, (2007) defined social networking sites as those "web-based services that allow individuals to: construct a public or semi-public profile within a bounded system; articulate a list of other users with whom they share a connection. Pp 11" Social media sites as they are popularly now called e.g. Twitter, YouTube, Myspace, Whatsup, Instagram, 2go, and Facebook, and many more are very popular online communication platforms among adolescents and emerging adults. The use of these sites might also be highly associated to not only a person's gender but also race, faith, ethnicity, family, parental educational background or social class (Boyd \& Ellison, 2007; Suleiman, 2014).

\section{SOCIAL MEDIA}

The paradigm now shifted and changed the concept from social networking sites to social media because it employs mobile and web based technology to create highly interactive platforms via which individuals and community share, cocreate, discuss and modifies user-generated content inform of news and general information (Kietzmannn, 2012; (Lenhart, et al, 2010).

Today social media is a phrase being tossed around a lot. He further stressed that it is a flexible website that does not just give you dynamic information but interact with you while giving you the information. It is a group of internet based application that allows the creation and exchange of users generated content. It is easy to confuse social media with social news because it is often refer to members of the news as the media. (Kietzmannn, 2012).

Lenhart and Madden (2007); (Lenhart, et al 2010) opined that "youths heavily use these sites". For instance as reported in Internet World Statistics, (2018) Nigeria population stands at 195,875,237 out of which the total numbers of 98,391,456 are internet users in the country which is $50.2 \%$ of the total population and is the highest in Africa. From this, almost 17,000,000 people use Facebook. Many among the population in Nigeria came to know of Facebook and Twitter through the media services for discussion on several topics related to Nigeria's socio-cultural, economical, educational and political issues (Suleiman, 2014).

\section{SOCIAL MEDIA AND ACADEMIC PERFORMANCE}

Though there have been many social, economic, and environmental factors that have added to the pressure of university students in the past ten years, the drop-out rate for students is still a major educational problem. Current statistics show that university students in Nigeria are under increased pressure due to higher academic standards in other countries, and it has become more important than ever for educators to encourage graduation and further education(Sharive, 2018; Suleiman, 2014). However, Bowen, (2008) further hold the view that with more and more students being preoccupied with social media networks use; it is estimated that even those students who do graduate from high school, one out of three do not possess the knowledge and skills that would lead him or her to the next level, such as college, polytechnics, universities or any other advanced training school.

According to Khan (2009), social media users often experience poor performance academically. Similarly, Englander, Terregrossa and Wang (2010) posit that social media is negatively associated with academic performance of student and is a lot more momentous than its advantages. Internet addiction consequently gave rise to internet usage within the last couple of decades. Nalwa and Anand (2013) stated that addicted users of internet are setting back their academic responsibilities which ultimately lead to poor academic performance. In the same vein, Karpinski \& Duberstein (2009) pointed out that social media users devoted lesser time to their studies in comparison to nonusers did. This subsequently led to having lower GPAs. Karpinski \& Duberstein (2009) mentioned that "among various unique distractions of every single generation, social media remains a major distraction of current generation. pp13"

\section{SOCIAL MEDIA AND SCHOOLS}

Social media networks, as well as other new forms of communication technology, are also a concern to many school professionals because of the level of distraction they create within the school (Greenfield \& Subrahmanyam, 2008). This has caused distractions during instruction time and has had a negative impact on the learning environment.

Das, and Sahoo, (2010) reported on transition difficulty among students. Suleiman (2014) asserted that academic adjustment as having dimensions and that transition for students from secondary school to university is greatly influenced by contemplation on their own way to take responsibilities for their own paths. His study concludes that using social media in form of faculty and student interaction strategy keeps the students firmly abreast with the school environment and boost their performance. This study also confirms that the university's provisions, settings, rules, regulations and interpersonal interactions among the students as well as with their teachers affect positively the students' academic adjustment and thus performance. 


\section{METHODOLOGY}

This study investigates the effects of social media on students' academic performance at the Federal College of Education, Kontagora, Niger State. Significantly this study would help both the teachers, parents and students. It will help the teachers of the school to understand the influence that social media has on their students so as to assist them to enlightening and creating awareness to students on the possible influence it has on their studies. The study is of significance to parents in the sense that they will be educated through its outcome on the possible effects these social media usage has on their children. It will enable the students be aware that, apart from the social benefits of this social networking site, using the sites more than necessary will pose possible dangers to their health. it will as well provide researchers with more information on the Influence of social media on student's academic performance.

The research design is a survey for investigation on the current status of a phenomenon of social media from which the information can be use for generalization. The population of this study comprises of all 6,769 students of Federal College of Education, Kontagora, Niger State. Some students were selected to be used as the sample which consists of students from various departments of Federal College of Education, Kontagora, Niger State. The sample was derived randomly by selecting 100 students from all level in the college. The instrument for data collection was four (4) Likert scale questionnaire. The respondents choose from the available options and ticked on selected option for each number. For data collection and analysis, copies of questionnaire were administered to the respondents; later retrieved, processed and analyzed using frequency and percentage. The result was presented in frequency distribution and in tabular form.

\section{RESULTS PRESENTATION AND DISCUSSION}

Below is the result on demography presentation of participants



Fig: 1: Age Group of the Respondents

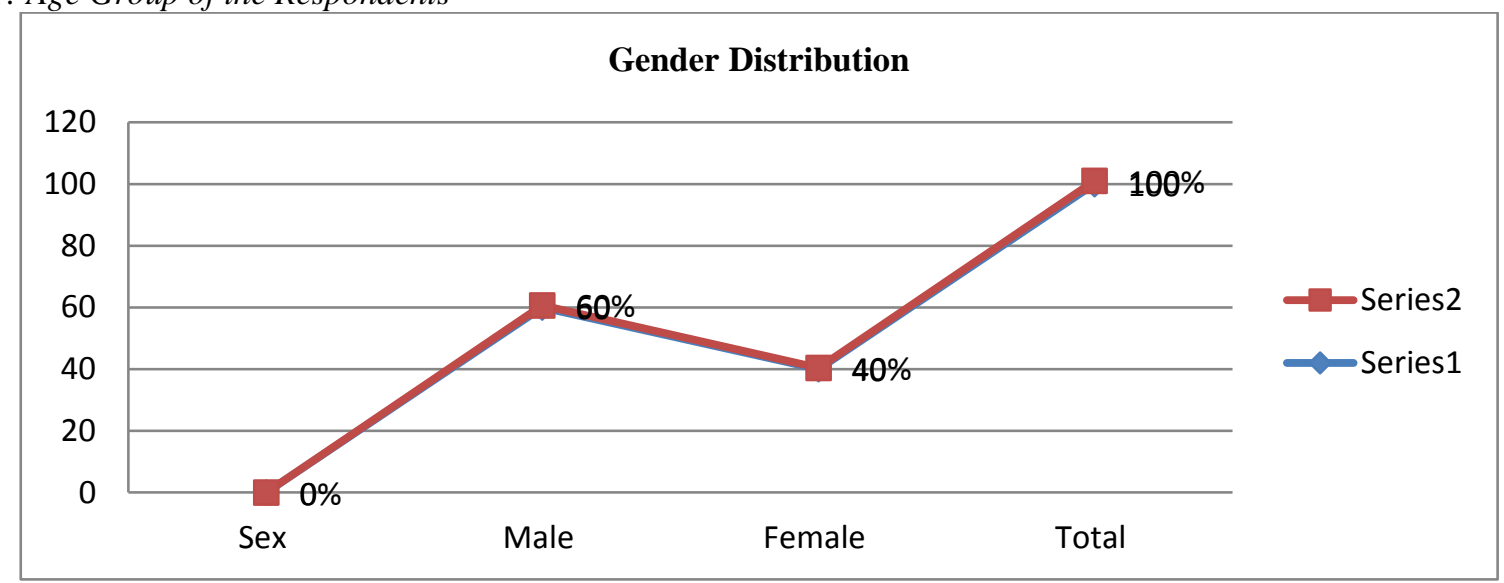

Fig: 2: Gender of the Respondents 


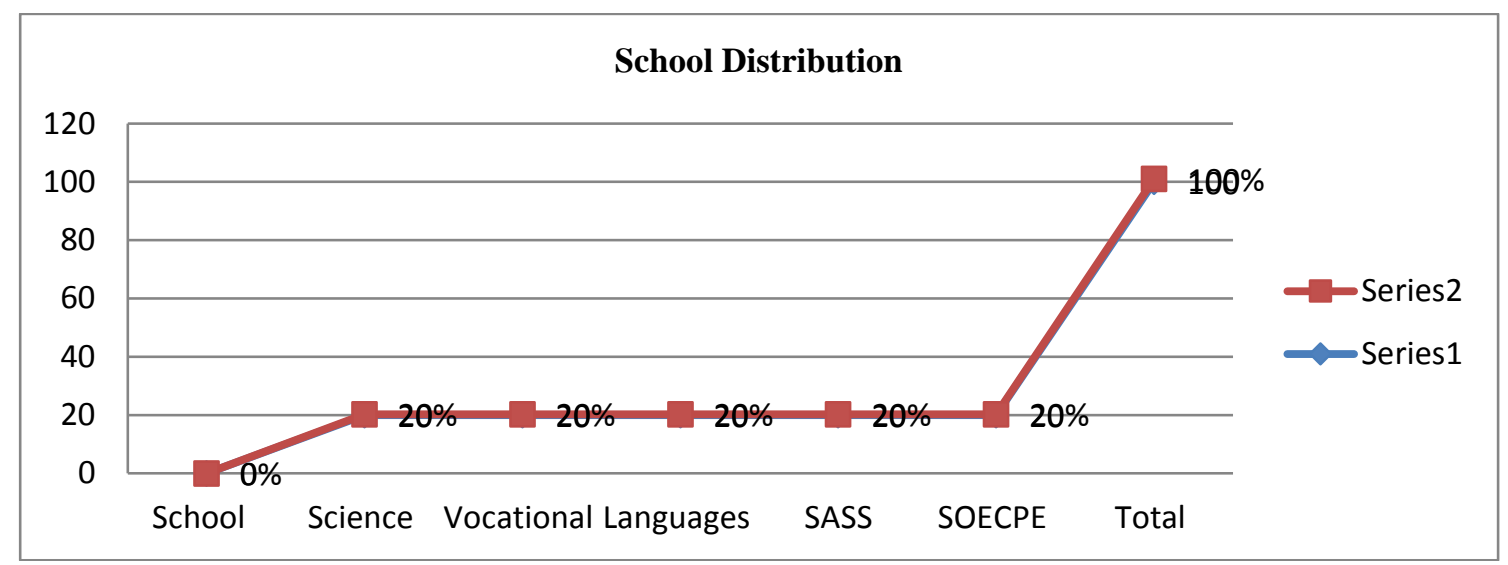

Fig: 3: School distribution of the respondents

Table 1: Demographic information of the respondents

\begin{tabular}{|l|c|c|}
\hline Item & Frequency & Percentage (\%) \\
\hline Age Group & & $62 \%$ \\
\hline $18-20$ & 62 & $25 \%$ \\
$21-23$ & 25 & $13 \%$ \\
$24-25$ & 13 & $\mathbf{1 0 0 \%}$ \\
Total & $\mathbf{1 0 0}$ & \\
\hline Sex & & $60 \%$ \\
\hline Male & 60 & $40 \%$ \\
Female & 40 & $\mathbf{1 0 0 \%}$ \\
Total & $\mathbf{1 0 0}$ & $20 \%$ \\
\hline School & & $20 \%$ \\
\hline Science & 20 & $20 \%$ \\
Vocational & 20 & $20 \%$ \\
Languages & 20 & $20 \%$ \\
SASS & 20 & $\mathbf{1 0 0 \%}$ \\
SOECPE & 20 & \\
Total & $\mathbf{1 0 0}$ & \\
\end{tabular}

Table 1 above shows that (62\%) of the respondents are of age 18-20, represent age (25\%) $21-23$, while (13\%) represent


the respondents according to schools as follows: Science, (20\%); Vocational, (20\%); Languages, (20\%); SASS, (20\%); and lastly SOECPE, $(20 \%)$.

The following is the result obtained with regard to the general influence and problems on students' academic performance. 
Research Question 1: To ascertain how the use of social media can influence the academic performance of the students.

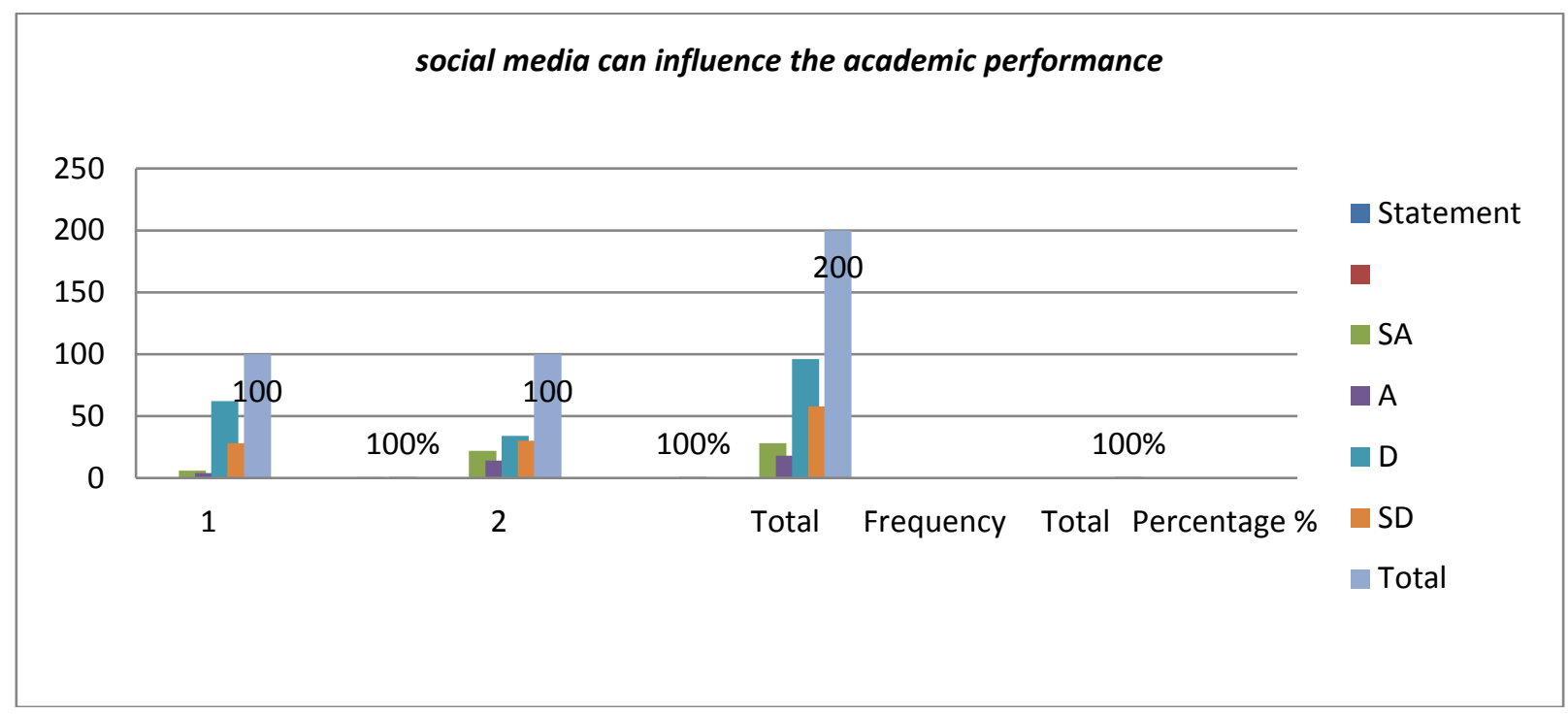

Fig: 2: social media can influence the academic performance of the students.

\begin{tabular}{|l|l|r|r|r|r|r|r|}
\hline S/N & Statement & & SA & A & D & SD & Total \\
\hline 1 & $\begin{array}{l}\text { Engaging in academic forums on social media } \\
\text { reduces their rate of understanding? }\end{array}$ & $\mathrm{F}$ & 6 & 4 & 62 & 28 & 100 \\
\cline { 2 - 7 } & $\%$ & $6 \%$ & $4 \%$ & $62 \%$ & $28 \%$ & $100 \%$ \\
\hline 2 & $\begin{array}{l}\text { They will not perform well in their academics even } \\
\text { if I stop using social media? }\end{array}$ & $\mathrm{F}$ & 22 & 14 & 34 & 30 & 100 \\
\cline { 2 - 7 } & $\%$ & $22 \%$ & $14 \%$ & $34 \%$ & $30 \%$ & $100 \%$ \\
\hline $\begin{array}{l}\text { Total } \\
\text { Frequency }\end{array}$ & $\mathrm{F}$ & $\mathbf{2 8}$ & $\mathbf{1 8}$ & $\mathbf{9 6}$ & $\mathbf{5 8}$ & $\mathbf{2 0 0}$ \\
\hline $\begin{array}{l}\text { Total } \\
\text { Percentage \% }\end{array}$ & $\%$ & $\mathbf{1 4 \%}$ & $\mathbf{9 \%}$ & $\mathbf{4 8 \%}$ & $\mathbf{2 9 \%}$ & $\mathbf{1 0 0 \%}$ \\
\hline
\end{tabular}

Table 2: social media can influence the academic performance of the students.

From the table 2 above disclosed that $14 \%$ of the respondents Strongly Agree the use of social media has influence on the students' academic performance, 9\% Agree, 48\% Strongly Disagree while the remaining 29\% Strongly Disagree. 
Research Question 2 Do the use of social media has any positive influence on students' academic performance?



Fig: 3: problems of individuals in using social media

\begin{tabular}{|l|l|r|r|r|r|r|r|}
\hline S/N & Statement & & SA & A & D & SD & Total \\
\hline 1 & $\begin{array}{l}\text { Social media affect the way of speaking or writing } \\
\text { in students' life? }\end{array}$ & $\mathrm{F}$ & 46 & 31 & 23 & - & 100 \\
\cline { 2 - 6 } & & $\%$ & $46 \%$ & $31 \%$ & $23 \%$ & - & $100 \%$ \\
\hline 2 & $\begin{array}{l}\text { Social media change the behavior of students } \\
\text { ineffectively? }\end{array}$ & $\mathrm{F}$ & 61 & 27 & 8 & 4 & 100 \\
\cline { 2 - 7 } & $\begin{array}{l}\text { Social media differentiates students on the bases of } \\
\text { their demography? }\end{array}$ & $\mathrm{F}$ & 14 & 9 & 48 & 29 & $100 \%$ \\
\cline { 2 - 7 } & $\begin{array}{l}\text { F } \\
3\end{array}$ & $14 \%$ & $9 \%$ & $48 \%$ & $29 \%$ & $100 \%$ \\
\hline $\begin{array}{l}\text { Total } \\
\text { Frequency }\end{array}$ & $\mathrm{F}$ & $\mathbf{1 2 1}$ & $\mathbf{6 7}$ & $\mathbf{7 9}$ & $\mathbf{3 3}$ & $\mathbf{3 0 0}$ \\
\hline $\begin{array}{l}\text { Total } \\
\text { Percentage \% }\end{array}$ & $\%$ & $\mathbf{4 0 \%}$ & $\mathbf{2 2 \%}$ & $\mathbf{2 7 \%}$ & $\mathbf{1 1 \%}$ & $\mathbf{1 0 0 \%}$ \\
\hline
\end{tabular}

Table 3: problems of individuals in using social media

From the table 3 above disclosed that $40 \%$ out of the total respondents Strongly Agree there are problems individuals faces in using social media, 22\% Agree, while 27\% Strongly Disagree and lastly the remaining 11\% Strongly Disagree.

\section{CONCLUSION}

The study concludes that social media sites such as Twitter, WhatsApp, Facebook, Instagram were the most that capture the attention of many students away from their study and thus affecting negatively and positively on their academic grade points aggregate. On these premise some recommendations were made.

\section{RECOMMENDATIONS}

In the light of the findings of this study, the following recommendations which concur to Sharive, (2018) are made:

1. Student users need to be educated on the effect of social media on their academic performance.

2. Student users need to be monitored and controlled on how they use social media during full academic activities and during exams.

3. Schools need to ensure that students use the social media only as a tool to improve the academic performance especially when in schools.

4. Students need to be managing their time of study time to avert distractions by the social media.

5. Social media sites need to review their pages to involve and to enhance academic activities. 
6. The student users need to balance the way they engage on these site especially on chit-chatting and academic activities.

7. The student users need to devote more attention and should be directed to research when using the social media

8. The student users need to focus more on the positive academic relevance than the negative purposes.

\section{REFERENCES}

- Ahmad, A., (2011, February). Rising of Social Network Websites in India Overview. IJCSNS International Journal of Computer Science and Network Security, 11, 155-158.

- Bowen, G., (2008). Preventing school dropout: The eco-interactional developmental model of school success. The Prevention Researcher, 16,3-8.Retrieved from http://www.TPRonline.org.

- Boyd, D., (2007).Why youth (heart)social network sites: The role of networked publics in teenage social life. Mac Arthur Foundation Series on Digital Learning-Youth, Identity, and Digital Media Volume. Cambridge, MA: MIT Press.1-26.

- Boyd, D. and Ellison, N., (2007). Social network sites: Definition, history, and scholarship. Journal of Computer-MediatedCommunication,13(1), 1-11.Retrievedfrom

- http://jcmc.indiana.edu/vol13/issue1/boyd.ellison.html.

- Das, D.B., and Sahoo, J.S., (2010). Social Networking Sites. A Critical Analysis of Its Impact on Personal and Social Life. International Journal of Business and Social Science.

- $\quad$ Englander, F., Terregrossa, R.A., and Wang, Z. (2010). Educational Review,62(1):85-96.

- Greenfield, P. and Subrahmanyam, K. (2008). Online communication and adolescent relationships. The Future of Children,18,119-140. Retrieved from: http://www.futureofchildren.org.

- Khan, U. (2009)."Facebook students under achieve in exams," Daily Telegraph, at

- $\quad$ http://www.telegraph.co.uk/education/educationnews/5145243/Facebook-students-underachieve-inexams.html

- Karpinski, A.C. and Duberstein, A.(April16,2009). A description of Facebook use and academic performance among undergraduate and graduate students. In Poster presented at the meeting of the American Educational Research Association, San Diego, CA.

- Kietzmann, H. (2012)."Social media? Getserious! Understanding the functional building blocks of social media". Business Horizons 54:241- 251.

- Lenhart, A., and Madden, M., (2007). Teens, Privacy \& online social networks: How teens manage their online identities and personal information in the age of My Space. Washington, DC.

- Lenhart, A., Purcell, K., Smith, A., and Zickuhr, K., (2010). Social media and young adults. retrieved from:

- http://www.pewinternet.org/reports/2010/social-media-and-young-aduts.html.

- Nalwa, K. and Anand, A.P., (2003). Internet addiction in students: a cause of concern. Cyber psychology and Behavior Journal, Vol. 6(6), 653-659.

- Shambare, R., Rugimbana, R., and Sithole, N., (2012). Social networking habits among students. African Journal of Business Management Vol. 6(2), 578-786.

- Sharive, P., (2018). Social Media And Academic Performance of Students in University of Lagos. A B.A(Ed), Research Project. Faculty of Education, University of Lagos, Available From: Https://Www.Researchgate.Net/Publication/273765197_Social_Media_And_Academic_Performance [Accessed Sep 12 2018].

- Suleiman A. A., (2014). Social Networking Site Usage as Tool for Social Capital and Academic Adjustment in the Nigerian Context. Presented On $17^{\text {th }}-18^{\text {th }}$ March 2014 at $21^{\text {st }}$ CAF 2014 in Harvard University USA.

- Zahid A., Ahmad M., Syed R. H. and Faisal H. (2016). Impact of Social Media of Student's Academic Performance. International Journal of Business and Management Invention ISSN (Online): 2319. www.ijbmi.org . Volume 5. Issue 4. of April. 2016. Pp. 22-29 